\title{
Evaluation of Plant Protection Practices of Garlic Growers in Gaziantep Province ${ }^{\#}$
}

\author{
Aydın Atakan 1,a,", Oktay Erdoğan ${ }^{2, b}$, Hülya Özgönen Özkayaa,c \\ ${ }^{1}$ Department of Plant and Animal Production, Araban Vocational School, Gaziantep University, 27840 Gaziantep, Turkey \\ ${ }^{2}$ Department of Organic Farming Business Management, School of Applied Sciences, Pamukkale University, 20690 Denizli, Turkey \\ ${ }^{3}$ Department of Plant Protection, Faculty of Agriculture, Isparta University of Applied Sciences, 32100 Isparta, Turkey
}

*Corresponding author

\begin{tabular}{|c|c|}
\hline A R T I C E I N FO & A B S T R A C T \\
\hline $\begin{array}{l}\text { "This study was presented orally at } \\
\text { the } 1^{\text {st }} \text { International Sustainable } \\
\text { Agriculture and Technology Congress } \\
\text { in Gaziantep on } 1-3 \text { April } 2019 \text { and } \\
\text { published as a summary text in the } \\
\text { proceedings book. } \\
\text { Research Article }\end{array}$ & $\begin{array}{l}\text { This study was carried out to determine the plant protection practices of the garlic growers in } \\
\text { Gaziantep province. For this purpose, a survey consisting of } 20 \text { questions and based on simple random } \\
\text { sampling method was conducted with } 81 \text { growers in each of the districts of Araban, Oguzeli, } \\
\text { Yavuzeli, Central, Nurdag1, Nizip and Karkamiş districts in } 2018 \text {. The data evaluated and expressed } \\
\text { as percent ratio. According to the findings from the surveys, garlic growers stated that they preferred } \\
\text { pesticide dealers suggestions for the selection and determination of doses of pesticides used in pests } \\
\text { and diseases, they also stated that the price and expiration date were not an important factor in the } \\
\text { selection of pesticides. In addition, it is found that growers avoid using the same pesticide } \\
\text { continuously against same diseases and pests, they do not make any changes in there commended } \\
\text { pesticide doses, pesticides leave residues on the products, they paid attention the time between the } \\
\text { last application and harvest. It has been reported that the use of protective clothing and mask during } \\
\text { the application by the growers is relative, they do not use pesticides as a mixture, they apply different } \\
\text { processes to empty pesticide boxes. It was determined that garlic growers prefered chemical control } \\
\text { and did not have knowledge about the concept of biopesticides. }\end{array}$ \\
\hline
\end{tabular}

Garlic growers

Chemical control

Pesticide dealer

Pesticide

Gaziantep

Türk Tarım - Gıda Bilim ve Teknoloji Dergisi, 8(9): 1942-1947, 2020

\section{Gaziantep İli Sarımsak Üreticilerinin Bitki Koruma Uygulamalarının Degerlendirilmesi}

\begin{tabular}{|c|c|}
\hline M A K A L E B İ L G İ S İ & Z \\
\hline $\begin{array}{l}\text { Anahtar Kelimeler: } \\
\text { Sarımsak üreticisi } \\
\text { Kimyasal mücadele } \\
\text { İlaç bayii } \\
\text { Pestisit } \\
\text { Gaziantep }\end{array}$ & $\begin{array}{l}\text { Bu çalışma, Gaziantep ili sarımsak üreticilerinin zirai mücadele konusundaki bitki koruma } \\
\text { uygulamalarının belirlenmesi için yürütülmüştür. Bu amaçla, } 2018 \text { yılında, basit tesadüfi örnekleme } \\
\text { yöntemine göre Araban, Oğuzeli, Yavuzeli, Merkez, Nurdağ1, Nizip ve Karkamış ilçeleri olmak üzere } \\
\text { her ilçede tesadüfi olarak seçilen toplam } 81 \text { üretici ile } 20 \text { soruluk anket çalışması yapılmıştır. Veriler } \\
\text { yüzde oran olarak ifade edilerek değerlendirilmiştir. Anketlerden elde edilen sonuçlara göre, sarımsak } \\
\text { üreticilerinin hastalık ve zararlılara karşı kullanılan pestisitlerin seçimi ve pestisit dozunun } \\
\text { belirlenmesinde ilaç bayilerinin önerilerini tercih ettikleri, fiyat ve son kullanma tarihinin pestisit } \\
\text { seçiminde önemli bir kriter olmadığı, aynı hastalık ve zararlılara karşı sürekli olarak aynı pestisiti } \\
\text { kullanmaktan kaçındıkları, önerilen dozda herhangi bir değişiklik yapmadıkları, ürünler üzerinde } \\
\text { pestisitlerin kalıntı bıraktığı, son ilaçlama ile hasat arasında geçmesi gereken süreye uydukları, } \\
\text { ilaçlama esnasında koruyucu elbise ve maske kullanımının göreceli olduğu, pestisitleri karışım } \\
\text { halinde kullanmadıkları, boş pestisit ambalajlarına farklı işlem uyguladıkları, yoğun olarak kimyasal } \\
\text { mücadeleyi tercih ettikleri ve biyopestisit kavramı hakkında bilgi sahibi olmadıkları saptanmıştır. }\end{array}$ \\
\hline
\end{tabular}




\section{Introduction}

Plants have been used by people from past to present for many purposes (Sevindik et al., 2017; Mohammed et al., 2018). The use of plants as nutrients, shelter construction, spices or medicinal materials stands out (Pehlivan and Sevindik, 2018; Mohammed et al., 2019). One of the first cultivated Allium strains, the motherland of garlic (Allium sativum L.) covers an area reaching Southern China on and stretching all the way to Tian Shan in Central Asia and from there it has reportedly spread to Central Asia, Africa, Europe and America around 10.000 years ago (Etoh and Simon, 2002; Ipek et al., 2008). Garlic, which is thought to have 400-600 varieties worldwide, is a plant with two subspecies (Anonymous, 2017). One of these subspecies is A. sativum var. sativum (soft necked) and the other is called A. sativum var. ophioscorodon (hard necked). The commonly grown garlic variety with an economic value in Turkey is A. sativum var. sativum. This plant is important both agriculturally and also for human health and currently it is mostly grown in Mediterranean countries, India, China and Far East and USA (Heinrich et al., 1996). In terms of global garlic production, Asian countries have a share of $65.0 \%$. Turkey is ranked seventh in the world with an approximate production share of $4.0 \%$ (Akca et al., 2017). According to 2017 data, 148.133 tons of dry and fresh garlic is being produced in a total area of 152.417 da annually in Turkey. The annual production in Gaziantep province is 25.505 tons in a total garlic cultivation area of $21.416 \mathrm{da}$. The garlic cultivation area in Gaziantep province comprises $14 \%$ of the total garlic cultivation area in Turkey and $17.2 \%$ of total production. In terms of national garlic production, Gaziantep province is ranked second, behind Kastamonu. In addition to Kastamonu and Gaziantep, the provinces producing garlic are Kahramanmaraş, Aksaray, Tokat, Konya, Adiyaman, Balıkesir, Hatay, Kütahya, Antalya, Tekirdag, Şanlıurfa and Edirne, respectively (TSI, 2017).

In general, having sufficient knowledge about plant protection methods and their correct application are very important for agricultural production. Plants are adversely affected by many diseases and pests during the growing period. Especially soil-borne diseases cause serious losses in crop production (Atakan and Ozgonen Ozkaya, 2018a). With regards to the crop protection methods practised by producers, several studies have been conducted in different regions and on different product groups in Turkey since early 1990s (Yucel et al., 1995; Boz et al., 1998; Yigit, 2001; Inan and Boyraz, 2002; Kadıglu, 2003; Gencsoylu and Baspinar, 2004; Emeli, 2006, Karatas and Alaoglu, 2011; Sentürk, 2013; Gedikli et al., 2015; Celik and Karakaya, 2017; Erdogan et al., 2017). Further to these studies, Ozkan et al. (2002) examined 83 growers in Serik and Manavgat districts of Antalya province, observing that producers are exceeding the recommended dosage levels and this leading to diseases. Demirci et al. (2005) conducted a survey on 108 producers in Ayaş and Nallıhan districts, defining the problems faced by tomato producers in Ankara. Onaran and Yanar (2012) conducted a survey in Kumluca, Finike and Demre districts of Antalya province to identify the crop protection methods practised by cucumber producers. Peker (2012) conducted a survey on
50 tomato producers from Çumra district of Konya province and reported that the most common method applied by them is chemical pesticides as they don't have much knowledge about other methods. Erdogan and Gokdogan (2017) conducted a study, through face-to-face interviews with 189 producers, to assess the crop protection practises of potato producers in Nevşehir province.

A literature review has been performed but no studies have been conducted on examining the plant protection problems faced by garlic growers in Gaziantep province. Therefore, the purpose of this study is to determine the attitudes and behaviours of garlic growers on plant protection practices in Gaziantep province.

\section{Material and Method}

Main data of the study have been acquired through surveys conducted to garlic producers in Araban, Oguzeli, Yavuzeli, Merkez, Nurdagı, Nizip and Karkamış districts of Gaziantep province in 2018. The survey form used in the study has been adopted to purpose from previously used survey forms (Erdogan and Gokdogan; 2017; Erdogan et al., 2017). Secondary data of the study have been gathered from domestic and international resources about crop protection productions and from data provided by Gaziantep Provincial Directorate of Agriculture and Forestry. In Gaziantep, there are 495 active farms producing garlic in Araban, Oguzeli, Yavuzeli, Merkez, Nurdag1, Nizip and Karkamış districts and the farms have been calculated within $95 \%$ confidence limits. The 20question survey forms were filled through face-to-face interviews with producers and data have been expressed in ratios and pieces. The number of surveys to be conducted for this study has been defined by using Simple Random Sampling Method (Cicek and Erkan,1996). Formula used for sampling;

$$
\mathrm{n}=\mathrm{N} \times \mathrm{S}^{2} \times \mathrm{t}^{2} /(\mathrm{N}-1) \mathrm{d}^{2}+\left(\mathrm{S}^{2} \times \mathrm{t}^{2}\right)
$$

In the equation; $n=$ Number of samples, $S=$ Population variance, $\mathrm{N}=$ Number of farms comprising population, $\mathrm{t}=$ Standard normal distribution value, $\mathrm{d}=$ Error concerning population.This study has been conducted within $95 \%$ confidence and $5 \%$ error limits and the number of surveys to be conducted has been defined as 81 , all of which have been randomly selected.

\section{Results and Discussion}

According to the outcomes of the surveys on studied garlic producers; $98.8 \%$ of the producers have been defined to be male and $1.2 \%$ to be female, and the ratio of primary school, high school and college/university graduates have been respectively revealed as $39.5 \%, 30.9 \%, 24.7 \%$ and $4.9 \% .58 .0 \%$ of the garlic producers are observed to have social security while $42.0 \%$ are not covered by any social security at all and $56.8 \%$ do not obtain any non-agricultural income (Table 1). 
According to the survey results, it has been concluded that the education levels of garlic producers in Gaziantep are low and the ratio of university graduate producers is varying when compared to other provinces. Inan and Boyraz (2002) reported that $50.0 \%$ of the producers in Konya province are primary school graduates and $12.8 \%$ are university graduates; while Kadioglu (2003) reported that $64.0 \%$ of the producers in Tokat are primary school graduates and $2.0 \%$ are university graduates. Acar and Gül (2015) have revealed $71.23 \%$ of the producers in Konya province are primary school graduates while $5.48 \%$ are university graduates. According to Erdogan and Gokdogan (2017), 64.6\% of the producers in Nevşehir province are primary school graduates and $1.1 \%$ are university graduates. Gozener et al. (2017) reported that $58.3 \%$ of the producers in Kazova district of Tokat province are primary school graduates but there are no university graduate producers. Further studies have concluded that $46.4 \%$ of the producers in Seyhan and Yüregir districts do not have any social security, $29.5 \%$ of them obtain non-agricultural income; $64.0 \%$ of the producers in Manisa do have social security while $66.0 \%$ of them do not obtain any nonagricultural income; $26.5 \%$ of the potato producers in Nevşehir province are not covered by any social security plan while $73.5 \%$ do have social security and $68.8 \%$ don't obtain any non-agricultural income (Emeli, 2006; Karatas and Alaoglu, 2011; Erdogan and Gokdogan, 2017).

Garlic producers have been observed to obtain an annual income of 49,530 $€$. On a similar base, producers in Alaçam, Terme and Bafra districts of Samsun province obtain an annual income of 38,300 ₹, (Gedikli, 2012); tomato producers in Kazova district of Tokat province obtain an annual income of 40,250 $€$, (Gozener et al., 2017); potato producers in Nevşehir province obtain an annual income of 30,393 £, (Erdogan and Gokdogan, 2017) and almond producers in Adryaman province obtain an annual income of 16,439 $\mathrm{E}$, (Erdogan et al., 2017). According to 2018 data, hunger level for Turkey is 1,738 E, (Anonymous, 2018), it is possible to say that garlic producers in Gaziantep province gained income above the hunger level.

The attitudes displayed by producers when it comes to selecting crop protection products have been indicated in Table 2. Results of the survey are similar to the results of previously studies. According to Inan and Boyraz (2002), producers in Konya observe the recommendations of pesticide dealers by $58.5 \%$, Provincial and District Agricultural Directorates by $34.3 \%$ and company representatives by $7.2 \%$, when selecting crop protection products. With regards to selecting pesticide for crop protection, $36.0 \%$ of the producers in Tokat asked for recommendations from pesticide dealers, $59.0 \%$ asked for recommendations from the Provincial Directorate of Food, Agriculture and Livestock and 4.0\% simply asked their neighbours for recommendations (Kadioglu, 2003). In a study conducted by Kalıpc et al. (2011), 35.8\% of the producers in Konya received recommendations from pesticide dealers, $24.1 \%$ used their own experiences, $15.0 \%$ asked to their neighbours, $11.6 \%$ asked for help from the Provincial Directorates of Agriculture and Forestry and affiliated directorates, 6.6\% sought help from agricultural engineers while $4.1 \%$ sought help from Chambers of Agriculture to select the adequate pesticides.
When making a selection of pesticide against diseases and pests, majority of garlic producers have specified that they base their decision on the active ingredient and brand of the pesticide (Table 3). According to Inan and Boyraz (2002), $15.7 \%$ of the tomato producers in Konya province base their decision on pesticide selection on its price. According to another study in Konya, $42.0 \%$ of tomato producers base their pesticide selection on the expiration date of the product (Peker, 2012). 87.5\% of tomato producers in Kazova district of Tokat province base their decision on pesticide selection on the price of the product (Gozener et al., 2017).

Table 1. Demographic information of garlic growers

\begin{tabular}{ll|r}
\hline \multicolumn{2}{c|}{ Demographic information } & $(\%)$ \\
\hline \multirow{2}{*}{ Gender } & Man & 98.8 \\
& Woman & 1.2 \\
\hline \multirow{3}{*}{ Education status } & Primary school & 39.5 \\
& Secondary school & 30.9 \\
& High school & 24.7 \\
& University & 4.9 \\
\hline \multirow{2}{*}{ Social security } & Yes & 58.0 \\
& No & 42.0 \\
\hline
\end{tabular}

Table 2. Information sources recommended by growers in the selection of pesticides

\begin{tabular}{l|r}
\multicolumn{1}{c|}{ Information source } & $(\%)$ \\
\hline Pesticide dealer & 61.7 \\
Neighbour recommendations & 1.2 \\
Own knowledge and experiences & 17.3 \\
Agricultural extension people recommendations & 9.9 \\
Special advisor recommendation & 9.9 \\
Total & 100 \\
\hline
\end{tabular}

Table 3. Factors affecting growers choice of plant protection products

\begin{tabular}{l|r}
\hline \multicolumn{1}{c|}{ Factors } & $(\%)$ \\
\hline Brand & 48.2 \\
Active ingredient & 43.2 \\
Price & 2.5 \\
Expiration date & 6.1 \\
Total & 100 \\
\hline
\end{tabular}

With regards to the diseases and pest occurring in production areas, $44.4 \%$ of the producers keep using the same pesticides all the time while $55.6 \%$ are changing the pesticide brand from time to time. $24.7 \%$ of the producers stated that they do not apply pesticides as soon as they observe a disease or pest. $55.0 \%$ of those producers base this decision on the belief that the harm is negligible and they start applying pesticides once an economic loss starts occurring. According to Boz et al. (1998), 42.2\% of the producers in Aydin province apply pesticides as soon as they observe a disease or pest; while Kadioglu (2003) reported that $52.2 \%$ of the producers in Tokat province apply pesticides regardless of the existence of any disease or pest.

An analysis of the criteria for pesticide-usage dose against chemical pest control has indicated that more than half of the producers base their dose adjustments on the recommendations provided by pesticide dealers (Table 4). A study conducted by Emeli (2006) has reported that 
$82.7 \%$ of the producers in Seyhan and Yüregir seek help from agricultural pesticide dealers for the correct dose of agricultural pesticides. According to the conclusions in other reports, $40.1 \%$ of the producers in İçel province, $37.2 \%$ of the farmers in Konya, $86.2 \%$ of the potato producers in Nevşehir determine the pesticide dosage under the supervision of pesticide dealers (Zeren and Kumbur, 1998; Inan and Boyraz 2002; Erdogan and Gokdogan 2017).

$83.9 \%$ of the producers have specified that they are applying the recommended dose without making any changes to it, while $16.1 \%$ are increasing the dose as they believe the recommended level is too low. Based on the findings, majority of the farmers do not increase the recommended dosage and this will help to increase the chances of succeeding in chemical pest control, reduce input costs, prevent the formation of resistance to a certain level and avoid phytotoxic effects. However, further to these effects, it is highly important to raise awareness among producers to ensure conscious agricultural practises. According to Peker (2012), 88.0\% of the farmers in Konya province observe the recommended dosage while $8.0 \%$ exceed the recommended dosage levels. Regarding the GAP (Southeastern Anatolia Project) region, 76.0\% of the producers apply the exact level of recommended dosage, $7.0 \%$ exceed it and 3.0\% apply a reduced level of dosage (Bayhan et al., 2015). Another study has reported that $52.8 \%$ of the producers in Konya province don't change the recommended dosage, $50.7 \%$ of the potato producers in Nevşehir also using the exactly the recommended levels of dosage (Inan and Boyraz 2002; Erdogan and Gokdogan, 2017).

This current study has revealed that producers have varying ideas about the pesticides leaving residue on products. According to the results obtained (Table 5), there is a need to inform the producers more adequately about pesticide residues. According to Inan and Boyraz (2002), $86.0 \%$ of the producers in Konya province believe that pesticides do not leave any residues on products and Erdogan and Gokdogan (2017) reported that $74.1 \%$ of the potato producers are in the same opinion.

$64.2 \%$ of the garlic producers stated that they observe the waiting time in pesticides, $27.2 \%$ never observe the waiting time while $8.6 \%$ observe it from time to time. According to Boz et al. (1998), 34.9\% of the producers in Aydın province don't observe the waiting time for harvesting; while Kadioglu (2003) reported that $91.0 \%$ of the producers observe the waiting time; $52.0 \%$ of the producers in Konya province are reported to disregard the waiting time (Kalıpc et al., 2011); while $80.0 \%$ of the potato producers in Nevşehir observe the waiting time (Erdogan and Gokdogan, 2017).

It has been observed that when spraying, $50.6 \%$ of the producers are not using any protective equipment, $34.5 \%$ are regularly using equipment and $14.9 \%$ are using occasionally. Erdogan and Gokdogan (2017) reported that $84.7 \%$ of the potato producers in Nevşehir province are not taking any protective measures; Boz et al. (1998) reported that $72.8 \%$ of the people involved in spraaying in Aydin province are not taking any protective measures; Peker (2012) reported that $52.0 \%$ of the producers in Konya are not using any protective equipment when spraying, while $16.0 \%$ are using a mask only. As a result, it has been revealed that the producers are ignoring protective measures when doing spraying and they are not interested in this issue.

Table 4. Information sources of growers determine the dose of pesticide

\begin{tabular}{l|r}
\hline \multicolumn{1}{c|}{ Information sources } & $(\%)$ \\
\hline Pesticide dealer & 67.9 \\
Neighbour recommendations & 2.5 \\
Own knowledge and experiences & 9.9 \\
Agricultural extension people recommendations & 7.4 \\
Special advisor recommendation & 12.3 \\
Total & 100 \\
\hline
\end{tabular}

Table 5. Opinion of garlic growers on pesticides leaving residues on products

\begin{tabular}{l|r}
\hline \multicolumn{1}{c|}{ Opinion } & $(\%)$ \\
\hline Leave no residue & 17.3 \\
Leave little residue & 50.6 \\
Leave residue & 32.1 \\
Leave a lot of residue & 0 \\
Total & 100 \\
\hline
\end{tabular}

Table 6. Usage ways of empty pesticide boxes of garlic growers

\begin{tabular}{l|r}
\hline \multicolumn{1}{c|}{ Usage ways } & $(\%)$ \\
\hline Let-in to land & 11.1 \\
Burning it & 60.5 \\
Throwing to randomly & 28.4 \\
Washing and using & 0.0 \\
Total & 100 \\
\hline
\end{tabular}

It is a pleasing thing to have observed that majority of the producers are burning the empty pesticide boxes after using them. Nevertheless, the rate of randomly thrown away empty pesticide boxes is also high (Table 6). A review of the issue in other studies has revealed that producers are following different methods when it comes to disposing of empty pesticide boxes. According to Akbaba (2010), the ratio of producers randomly throwing away empty pesticide boxes in Çukurova region is $61.1 \%$. $37.5 \%$ of the producers in Seyhan and Yüregir leave the empty boxes on the side of the field, $32 \%$ are burning them, $20.5 \%$ are using them for different purposes and $10.0 \%$ are just throwing them away randomly; $43.0 \%$ of the producers in Menemen randomly throw away the empty pesticide boxes, $18.0 \%$ are burning them, $65.3 \%$ of the producers in Manisa wash empty pesticide boxes, $24.0 \%$ throw it away randomly to nature and $10.7 \%$ bury it, $76.3 \%$ of the producers in Nevşehir dispose of packaging by burning them, $15.1 \%$ bury it and $8.6 \%$ leave it in nature (Emeli 2006; Demirkan and Uysal 2011; Karatas and Alaoglu, 2011; Erdogan et al., 2017).

In this current study, $95 \%$ of the producers stated that they clean their spray tank after spraying while 5\% keep using it without cleaning. The findings of this current study show great similarities to the findings of other survey studies. $95.8 \%$ of the potato producers in Nevşehir province clean the spray tank following spraying while 4.2\% are not cleaning it (Erdogan and Gokdogan, 2017). $85.42 \%$ of the producers in Manisa province wash the 
spraying device after spraying while $14.58 \%$ are not washing it (Erturk et al., 2012).

$79 \%$ of the producers have reported to use the pesticides without any mixing while the remaining $21 \%$ are mixture them. The findings of this current study show great similarities to the findings of other survey studies. It has been reported that $57.4 \%$ of the producers in Tokat are using a mixture of pesticides, $56.0 \%$ of the producers in Adana are also mixing pesticides, $24.0 \%$ of them are using a single pesticide and $20.0 \%$ of them are sometimes mixing the pesticides (Kadıoglu, 2003; Peker, 2012).

$82.7 \%$ of the garlic producers specified that they prefer chemical control. The control methods other than chemical control are as shown in Table 7. Pesticides have many harmful effects (Atakan and Ozgonen Ozkaya, 2018b). Obtained this result is very high and the level of awareness of garlic growers should be increased. Therefore, including environmentally friendly applications such as the use of Arbuscular mycorrhizal fungi in biological control can eliminate the harmful effects of these chemicals (Atakan et al., 2018). In contrary to the current findings, Kadioglu (2003) reported that $43.5 \%$ of the producers in Tokat prefer cultural control methods, $33.3 \%$ prefer mechanical control methods and $23.0 \%$ prefer physical control methods; while according to Erdogan and Gokdogan (2017), 88.4\% of the potato producers in Nevşehir prefer cultural control while $10.5 \%$ prefer mechanical control.

Table 7. Control methods outside of chemical control of garlic growers

\begin{tabular}{l|c}
\hline \multicolumn{1}{c|}{ Control methods } & $(\%)$ \\
\hline Cultural control & 6.2 \\
Mechanical control & 1.2 \\
Physical control & 3.7 \\
Biological control & 6.2 \\
Total & 100 \\
\hline
\end{tabular}

\section{Conclusion}

In this current study, majority of garlic producers have specified that they are seeking advice from public institutions and organizations and also from people with knowledge when they need to decide on a specific pesticide, that they are basing their pesticide selection on the brand or active substance, more than half of the producers are not using the pesticides as a mixture and they are observing the waiting time between spraying and harvest but they are not using protective clothing and mask when performing spraying, they are adjusting the dose levels on the basis of recommendations received from pesticide dealers and they act carefully on the matter of increasing or decreasing the pesticide dose, they are taking care of the cleanliness of the spraying tool and dispose of the empty pesticide boxes. In the meantime, the fact that $17.3 \%$ of garlic producers declared that pesticides do not leave any residue on products, the fact that all control methods except chemical control have a low rate of applicability and the fact that bio-pesticide is far from being well-known (only 3.7\%) are worth considering and they are among topics to be elaborated.
In conclusion, it is of a great importance to carry out trainings for farmers and projects to raise awareness on crop protection applications for garlic producers and thus minimize or eliminate problems regarding the applications of chemical control. The data to be found with this practise will be enlightening to agricultural public institutions and offices, agricultural pest control products dealers, agricultural publication personnel, farmers and researchers.

\section{References}

Acar M, Gül M. 2015. Havuç Yetiştiriciliginin Teknik Yapısı ve Degişimi: Konya İli Örnegi. Mustafa Kemal Üniversitesi Ziraat Fakültesi Dergisi, 20(1): 43-53.

Akbaba BZ. 2010. Adana İli Turunçgil Yetiştiriciligi ve İnsektisit Kullanımının Degerlendirilmesi. Yüksek Lisans Tezi, Fen Bilimleri Enstitüsü, Çukurova Üniversitesi, Adana. Türkiye.

Akca H, Taban N, Turan MA, Taban S, Ouedraogo AR, Türkmen N. 2017. Türkiye'de sarımsak tarımı yapılan toprakların verimlilik durumu. Toprak Bilimi ve Bitki Besleme Dergisi, 5(2): 93-100.

Anonymous, 2017. In Garlic Varieties. http://unlimitedrecipes.com/types-of-garlic_[Accessed 27 January 2019]

Anonymous, 2018. Türkiye İşçi Sendikaları Konfederasyonu (Türk-İş). http://www.turkish.org.tr. [Accessed 9 January 2019]

Atakan A, Ozgonen Ozkaya H. 2018a. Antalya İli Karanfil Seralarında Toprak Kökenli Fungal Hastalık Etmenlerinin Yaygınlıgının Belirlenmesi. Süleyman Demirel Üniversitesi Fen Bilimleri Enstitüsü Dergisi, 22(1): 216-220.

Atakan A, Ozgonen Ozkaya H. 2018b. Fitopatolojide Nanoteknoloji. Harran Tarim ve Gida Bilimleri Dergisi, 22(2): 296-303.

Atakan A, Ozgönen Ozkaya H, Erdogan O. 2018. Effects of Arbuscular Mycorrhizal Fungi (AMF) on Heavy Metal and Salt Stress. Turkish Journal of Agriculture - Food Science and Technology, 6(11): 1569-1574.

Bayhan E, Sagır A, Uygur FN, Bayhan SO, Eren S, Bayram Y. 2015. GAP Bölgesi pamuk alanlarındaki bitki koruma sorunlarının belirlenmesi. Türkiye Entomoloji Bülteni, 5(3): 135-146.

Boz O, Erol T, Benlioglu S, Oncuer C. 1998. Aydın ilindeki zirai mücadele uygulamalarının sosyo-ekonomik yönden degerlendirilmesi. Türkiye Entomoloji Dergisi, 22(2): 123136.

Celik A, Karakaya E. 2017. Bingöl İli Adaklı İlçesi Elma Üreticilerinin Tarımsal İlaç Kullanımında Bilgi Tutum ve Davranışlarının Degerlendirilmesi ve Ekonomik Analizi. Türk Tarım ve Doga Bilimleri Dergisi, 4(2): 119-129.

Ciçek A, Erkan O. 1996. Tarım Ekonomisinde Araştırma ve Örnekleme Yöntemleri. Gaziosmanpaşa Üniversitesi Ziraat Fakültesi Yayınları No:12, Tokat.

Demirci F, Erdogan C, Tatlıdil FF. 2005. Ankara İli Ayaş ve Nallıhan İlçelerinde Domates Üretim Alanlarında Zirai Mücadele Uygulamaları. Tarım Bilimleri Dergisi, 11 (4): 422-427.

Demirkan H, Uysal F. 2011. Menemen (İzmir) Pamuk Üreticilerine Yönelik (Bitki Koruma Açısından) Bir Anket Çalışması. Ege Üniversitesi Ziraat Fakültesi Dergisi, 48 (3): 277-282.

Emeli M. 2006. Seyhan ve Yüregir Havzasında Bitki Koruma Yöntemlerinin Uygulamadaki Sorunları Üzerine Bir Araştırma. Yüksek Lisans Tezi, Fen Bilimleri Enstitüsü, Çukurova Üniversitesi, Adana, Türkiye.

Erdogan O, Gokdogan O. 2017. Nevşehir ilinde patates üreticilerinin bitki koruma uygulamaları. Batı Akdeniz Tarımsal Araştırma Enstitüsü Derim Dergisi, 34(1): 51-60. 
Erdogan O, Tohumcu E, Baran MF, Gokdogan O. 2017. Adıyaman İli Badem Üreticilerinin Zirai Mücadele Uygulamalarının Degerlendirilmesi. Türk Tarım-Gıda Bilim ve Teknoloji Dergisi, 5(11): 1414-1421.

Erturk YE, Bulak Y, Uludag A. 2012. Igdır ili tarım işletmelerinin zirai mücadele uygulamalarında çevreye duyarlılıkları. Tarih Kültür ve Sanat Araştırmaları Dergisi, 1(4): 393-401.

Etoh T, Simon PW. 2002. Diversity, Fertility and seed production of garlic. In Rabinowitch HD, Currah L. (Eds.), Allium crop science: recent advaces, CAB International. UK. pp. 101-111.

Gedikli O, Uzundumlu AS, Tozlu G. 2015. Çeltik, misır ve bugday üretiminde tarımsal ilaç kullanımının çevresel duyarlılık yönünden incelenmesi: Samsun ili örnegi. TÜBAV Bilim Dergisi, 8(2): 19-26.

Gedikli O. 2012. Samsun İli Alaçam, Bafra ve Terme İlçeleri Üreticilerinin Bitki Koruma Yönünden Karşılaştıkları Sorunlar ile Tarımsal İlaç Kullanım Durumunu Etkileyen Faktörlerin Degerlendirilmesi. Yüksek Lisans Tezi, Fen Bilimleri Enstitüsü, Atatürk Üniversitesi, Erzurum, Türkiye.

Gencsoylu I, Baspınar H. 2004. Büyük Menderes havzası pamuk ekim alanlarında üreticilerin zararlılara karşı yaptıkları kimyasal mücadele uygulamalarının genel degerlendirilmesi. Adnan Menderes Üniversitesi Ziraat Fakültesi Dergisi, 1(1): 7-11.

Gozener B, Sayılı M, Caglar A. 2017. Tokat İli Kazova Bölgesinde Domates Yetiştiriciliginde İlaç Kullanımı. Türk Tarım Gida Bilim ve Teknoloji Dergisi, 5(5): 451-458.

Heinrich PK, Larry DL. 1996. Garlic. The science and the rapeutic application of Allium sativum L. and related species, Williams and Willkins, 351 West Camden Street, Baltimore, Maryland, USA.

Inan H, Boyraz N. 2002. Konya çiftçisinin tarım ilacı kullanımının genel olarak degerlendirilmesi. Selçuk Üniversitesi Ziraat Fakültesi Dergisi, 16(30): 88-101.

Ipek M, Ipek A, Simon PW. 2008. Molecular characterization of Kastamonu garlic: An economically important garlic clone in Turkey. Scientia Horticulturae, 115(2): 203-208.

Kadıglu I. 2003. Tokat İlinde Üreticilerin Zirai Mücadele etkinlikleri Üzerinde Bir Araştırma. Gaziosmanpaşa Üniversitesi Ziraat Fakültesi Dergisi, 20(1): 7-15.

Kalıpcı E, Ozdemir C, Oztaş H. 2011. Çiftçilerin pestisit kullanımı ile ilgili egitim ve bilgi düzeyi ile çevresel duyarlılıklarının araştırılması. TÜBAV Bilim Dergisi, 4(3): 179-187.
Karatas E, Alaoglu O. 2011. Manisa ilinde üreticilerin bitki koruma uygulamaları. Ege Üniversitesi Ziraat Fakültesi Dergisi, 48(3): 183-189.

Mohammed FS, Akgul H, Sevindik M, Khaled BMT. 2018. Phenolic content and biological activities of Rhus coriaria var. zebaria. Fresenius Environmental Bulletin, 27(8): 56945702 .

Mohammed FS, Karakaş M, Akgul H, Sevindik M. 2019. Medicinal Properties of Allium calocephalum Collected from Gara Mountain (Iraq). Fresen Environ Bull, 28(10): 74197426.

Onaran A, Yanar Y. 2012. Antalya İli'nin Demre, Finike ve Kumluca İlçelerinde Hiyar Yetiştiren Sera İşletmelerinde Çiftçi Uygulamaları Üzerine Bir Araştırma. Gümüşhane Üniversitesi Fen Bilimleri Enstitüsü Dergisi, 2 (2): 112-122.

Ozkan B, Vuruş H, Karaman S, Taşçıoglu Y. 2002. Antalya İlinde Serada Sebze Üretiminde Pestisit Kullanımının Ekonomik Açıdan Degerlendirilmesi. Bahçe, 31(1): 9- 16.

Pehlivan M, Sevindik M. 2018. Antioxidant and antimicrobial activities of Salvia multicaulis. Turkish Journal of Agriculture-Food Science and Technology, 6(5): 628-631.

Peker AE. 2012. Konya ili domates üretiminde tarımsal ilaç kullanımına yönelik çevresel duyarlılık analizi. Igdır Üniversitesi Fen Bilimleri Enstitüsü Dergisi, 2(1): 47-54.

Senturk CO. 2013. Çeltik Üretimi Yapan Tarım İşletmelerinde Tarımsal İlaç Kullanımında Yayım Yaklaşımları: Edirne İli Örnegi. Yüksek Lisans Tezi, Fen Bilimleri Enstitüsü, Namık Kemal Üniversitesi, Tekirdag, Türkiye.

Sevindik M, Akgul H, Pehlivan M, Selamoglu Z. 2017. Determination of therapeutic potential of Mentha longifolia ssp. longifolia. Fresen Environ Bull, 26(7): 4757-4763.

TSI, 2017. Turkish Statistical Institute. www.tüik.gov.tr, Available from:[Accessed 22 January 2019]

Yigit F. 2001. Antalya ilinde zirai ilaç bayilerinin genel durumları ve çiftçi ile olan ilişkilerinin araştırılması. Türk-Koop Ekin Dergisi, 5(15): 90-96.

Yucel A, Çıkman E, Yucel Mİ. 1995. Güneydogu Anadolu Bölgesi (GAP) Uygulamaya Konulmadan Önce Harran Ovasında Çiftçinin Tarımsal Mücadeleye Bakışı. GAP Bölgesi Bitki Koruma Sorunları ve Çözüm Önerileri Sempozyumu, 27-29 Nisan 1995. Şanlıurfa.

Zeren O, Kumbur H. 1998. İçel ilinde tarımsal ilaç pazarlama kullanım teknigi ve etkinligi üzerine araştırmalar. Türk-Koop Ekin Dergisi, 2(5): 62-68. 